\title{
INVESTIGATING THE GAP OF ARBITRATION IN IRANIAN
}

\section{LAW}

\author{
Masuod Palizban ${ }^{1}$ \\ Siamak Jafarzadeh ${ }^{2}$ \\ Reza Nikkhah Sarnaghi ${ }^{3}$
}

\begin{abstract}
The existence of family evolution of legislation in arbitration, disputes is influenced by the complicated social conditions and circumstances at present. If a dispute occurs between the couples, it is necessary that the government extirpate the source of dispute and make peace between the couples. In Iranian law, this institution is referred as arbitration. Arbitration is a Quranic solution for the settlement of family disputes and this Qur'anic verdict has been taken into consideration by the examining the current law of arbitration and explaining the legal defects in Iranian law are studied by the descriptive-analytical method. Finally, it is suggested that the judicial system along with the family courts constitutes the required numbers of arbitration branches comprised of legal experts, family counselors and a psychologist to help the court for settlement of family disputes.
\end{abstract} legislators and regulations were enacted in this regard. Differences in jurisprudential views and changing

Keywords: Arbitrator, arbitration, laws, reconciliation of two parties, no fault divorce.

social conditions have caused changes in the current positive laws in the field of arbitration; however, there are shortcomings in this law. In this research, the arbitration principles, the

\section{Introduction}

Marriage is one of the human being needs, and it has been widely

\footnotetext{
${ }^{1} \mathrm{PhD}$ student, Department of Islamic jurisprudence and law, Urmia University, Urmia, Iran. Email: mapalizban@yahoo.com.

${ }^{2}$ Assistant Professor, Faculty of Literature and Humanities, Department of Islamic, Urmia University, Urmia, Iran. jurisprudence and law. Email: s.jafarzadeh@urmia.ac.ir. ${ }^{3}$ Assistant Professor, Faculty of Literature and Humanities, Department of Islamic, Urmia University, Urmia,Iran.jurisprudence and law. Email: r.nikkhah@urmia.ac.ir.
} 
recommended in the religion of Islam. As Prophet Muhammad (pbuh) says: "Marriage is my tradition and whoever avoids this tradition, is not a Muslim". (Martyr Sani, Jame alakhbar 1992) Although marriage is the first step in the path of marital life, its maintenance is more important than beginning the marital life. This matter is not possible except if the couples observe each other's rights which their details are determined in the religious laws of Islam.

But sometimes one of the couples or both of them does not pay attention to the duties that they have to do for each other, which cause disputes between the couples and failure in resolving these disputes leads to divorce. Therefore, it is necessary that if a slight dispute occurs, to resolve it immediately and prevent the dispute to get worse. The best way is that individuals with good intention, experience and insight in family affairs and also willing to solve the problem, interfere in these disputes to resolve them. The Holy Quran calls these individuals as Hakam (the judge) (Surah An-Nisa, 35), and it is interpreted as the arbitrator in Iranian law; which their presence and interfere at the right time, help to prevent the disputes to get worse. The legal bill of the special civil court, instead of the lack of compromise probability, referred to the "divorce permission" which gives the husband the permission of divorce; which means that if the court could not make compromise between the couple by determining an arbitrator, so gives the husband the permission to get divorce. ${ }^{4}$ (Taheri, 1997) In accordance with the regulations, all individuals have the right to resolve their conflict by referring to one or more arbitrators. It does not matter, whether they preferred the dispute in the court or not or even if they have preferred, this process is in what stage. The advantage of this way is that through it, the litigants without any bureaucracy resolve their disputes by plain language and sometimes with lower cost. (Jalali, 2009) However, this study attempts to consider the gaps of the arbitration law in divorce.

\section{Arbitration principles}

The allowance and influence of arbitration which is referred to as

\footnotetext{
${ }^{4}$ Note 2, Clause 3, Special civil law.
} 
consolidated judgment in Islamic law is documented in the holy verse: "And if you fear a breach between the two, then appoint judge from his people and a judge from her people; if they both desire agreement..." (Surah An-Nisa, 35). The provisions of the verse confirm the allowance and influence of the arbitration in family disputes that can be extended to similar disputes by setting aside the property. Therefore, at least, the principle of arbitration is confirmed by Islamic law. In addition to the above verse, other verses can be found in the Holy Quran that in some way imply the arbitration or compromise. (An-Nisa, 59-65, Al-Hujurat, 9-10) On the other hand, there are several narratives about authorization of arbitration. Most of these narratives are quoted from Sunni books. Some of the narratives that they relying on are as follows: the Prophet's (PBUH) action for the verdict that he issued between Sa'd ibn Mu'adh's and Banu Qurayza, his verdict for women narrative (Heydar, Sivasi and Ghazizadeh 1937) Morsaleh (Ibn Ghodameh, 1972) and Mashhuri which is also relied by Shia jurists. (Najafi 1983, Martyr Sani 1992, Hoseini Shirazi 1998) In addition to the above reasons, Sunni tend to rely on the consensus of companions on the consolidation awards, and thus they consider the verdict to consolidation allowance or arbitration based on the book, and they believe the tradition and consensus are constant. (Heydar, Sivasi and Ghazizadeh 1937) Morsaleh (Ibn Ghodameh, 1972)

The most important narrative in the book of Shia narrations about arbitration is the news of Ahmad ibn Fazl Kennasi Azkashi from Imam Sadiq (AS). (Horr Ameli, 1983) However, because of the deniable appearance of statements, there are doubts that the narrative refers to the consolidation allowance (Najafi 1983, Hoseini Shirazi 1998), so Shia jurists mostly rely on the consensus on order to authorize the arbitration. (I bid)

In any case, what is certain is that there is no relatively comprehensive text in the field of Islamic jurisdiction that does not cover the issue of arbitration and its conditions. This is certainly a reason for consensus of the experts of Islamic law in the allowance and influence of arbitration even though briefly.

\section{Arbitration developments in} Iranian Legal System 
Given the fact that arbitration has changed a lot in the legal developments of Iran, it is necessary to briefly examine these developments:

2.1. For the first time, the Clause 676 of the Code of Civil Procedure, approved in 1939, states: "In the case of a dispute between wife and husband due to the misconduct, lack of obedience, alimony, the right of clothing, the right of habitation and child expenses whom the husband is responsible for and is also in the custody of wife; if one of the couples initiates the suit, the courts can refer the suit to the arbitration with the willing of each of litigants and in case that they do not accord on determining the arbitrator, they can choose at least two people of their relatives and if they don't have any relatives in their living region, they can choose from their friends. The arbitrator is obligated to make compromise between litigants as far as possible and if he fails, presents his decision to the court in identifying the one who is in the right and determining the expenses of wife or child, if the issue of suit is about the expenses".

According to this Clause, firstly the arbitration does not assign to divorce and it is for all the issues and affairs of family life. Secondly, referring the matter to the arbitration is performed by willing of one of the litigants. Thirdly, the court is not required to refer the matter to arbitration.

2.2. In the Clause 6-5, the Family Protection Act, approved in 1974, is about the arbitration, Article 5: "The court, upon request of either litigant, is obligated to refer the issue of the suit to one to three arbitrators, except for investigating the principle of marriage and divorce. The court will also directly refer the suit to the arbitration, if it is necessary..."

Clause 6: "The arbitrator or arbitrators will try to make compromise between the litigants and if they fail, they will declare their opinion on the nature of the proceedings in the written form to the court in the specified period of time. This opinion is communicated to the litigants 
in order to declare their opinion to the court within ten days. If the litigants agree with the opinion of the arbitrator, the court issues the arbitration verdict; unless the arbitrator's decision is in contrast with the justifiable rules that in this case, the verdict will nullify. Whenever one of the litigants objects to the decision of arbitrator, or does not respond in the specified time, or the arbitrator's decision be in contrast with the justifiable rules; the court will proceed to the matter and depending on the case, issue a proper verdict or certify the lack of probability to compromise".

In this law, firstly, the arbitration is not assigned to the divorce and it is for all the issues and affairs of family life as well. Secondly, referring the matter to the arbitration is performed by willing of one of the litigants. Thirdly, the court is obligated to refer the matter to arbitration. Fourth, in the absence of any objection from the litigants to the arbitrator decision, the court will issue according to the arbitrator verdict.

2.3 in the note 2 of article 3 of special Civil Court bill approved in 1979 it is stated that: "divorce cases are the same as those prescribed in civil law and religious law, but in cases that the husband applies for divorce relying on article 1133 of civil law, according to the verse "If you fear a breach between them, appoint one arbiter from the people of the man and one from the people of the woman. If they wish to have a settlement then God will reconcile them, for God is all-knowing and cognizant." and if couples do not compromised, the court refers the case to arbitration. Divorce will be allowed. In the cases that the couples have agreed upon divorce, going to the court is not necessary." In accordance to the above note, first, the reference is only possible if the apply for divorce is stated and it is on behalf of the husband. Secondly, for the reference, there is no need for couple's request, and the court is obliged to refer the case to the arbitration.

2.4 The latest legislation is about arbitration in family disputes, in the law of divorce provisions amendment approved in 1991 by Expediency Discernment Council. In the single article of this law, it is stated that:

"Since the adoption of this law, couples intending to divorce and separate from one another, must go to special civil court to resolve their dispute and initiate suite. If the dispute between couples is not dissolved by the court and arbitrators of two parties chosen by the 
court, as what Holy Quran has said, the court will send them to divorce registry office by issuing the certificate of incompatibility. Divorce registry offices do not have the right to file the divorces for which the certificate of incompatibility has not been issued. Otherwise, the offender notary will be disqualified". In the first note of this article, the manner of inviting the arbitrators and investigating their qualification is entrusted to a special civil court that performs that by using executive by-law. In accordance with this by-law, firstly, reference is only related to the divorce and other family disputes are not included in this by-law. Secondly, the court does not choose an arbitrator by initiating suit for divorce by each party, but the court itself initiates a compromise process, and if the dispute between two parties is not dissolved through the court, the case will be referred to arbitration by issuing the writ. Thirdly, the reference includes no-fault divorces, such as the divorce granted at the woman's request (Khula).

\section{Study of current law of arbitration}

The last divorce reform act was approved by Expediency Discernment
Council on 28 October 1992; the by-law of its note that was approved on 21 March 1992 will be reviewed below:

\section{1 actions requiring arbitration}

Of all marriage actions, such as actions of obligation to maintenance, obligation to obedience, demanding dowry, divorce, etc., only the divorce action requires the intervention of arbitrator, according to legislator's prescription. There is also no difference in type of divorce and divorce applicants. In other words, if the divorce is applied by man or woman, or if the divorce is agreed upon by the parties, the couple's dispute must be referred to arbitration.

\section{2 time of the reference}

By filing a claim for divorce by couples or one of them, the court cannot at first refer the parties to arbitration, but must first attempt to dissolve the dispute. If the court did not succeed in reaching outcome, and the disputes were not dissolved by direct intervention, the proceeding would continue through reference. Therefore arbitrators in the divorce are substitutes of the court, and 
they intervene in a dispute that the court is unable to resolve the dispute.

\subsection{How to select arbitrators}

After the court issued the reference order, each of the parties shall introduce one of their relatives who are qualified for arbitration stated in the bylaw, within 20 days since the date of service. If there is not a qualified person among relatives or they are not available, or refuse to accept the arbitration, each of the couples can choose their arbitrator among others who are qualified, and if they are not able to introduce an arbitrator or refuse to introduce him, the court will appoint an arbitrator from qualified people.

\subsection{The conditions of arbitrators}

In accordance with Article 4 of the by-law of appointed or selected arbitrator, six conditions must be fulfilled: Muslim, relative familiarity with religious, family and social issues, being at least forty years old, married, trustworthy, and not being reputed to sinfulness and corruption. The gender of arbitrators was not considered by the legislator, so both the man and the woman can be chosen or appointed as an arbitrator.

\section{5 steps of arbitration}

Determining arbitrators and accepting arbitration of their behalf; the court must set a time and remind the arbitrators their duties and how to act, and also specify the deadline that the arbitrators must submit their opinions about the dispute to the court. The arbitrators must convene at least two meeting with the parties to examine the problems that caused the dispute and try to dissolve the dispute and reach the reconciliation of two parties by presenting appropriate solutions. The absence of either of the couples or one of them in the meetings does not interfere its holding and the arbitrators must, in any case, examine the cases of dispute and submit their opinion about possibility or impossibility of compromise within determined deadline. If the determined deadline is not sufficient for arbitration, the arbitrators can request the court to prolong the deadline, and if the court finds the request necessary, the time will be prolonged. The arbitrators can ask for remuneration, and the court will 
determine their remuneration and will order to pay and receive it to the arbitrators (Naji, 1970; Abdul Hamid, 1989).

\section{Comparison of the arbitration and} Dispute Settlement Council

\section{Law of Dispute Settlement} Councils approved on 1 July 2008, in Articles 12-13 deals with family lawsuits and has allowed the courts to refer the case to the Dispute Settlement Council, considering the quality of lawsuit or dispute and the possibility of its settlement through compromise. Referring the case to the council, the members of this authority must try to dissolve the dispute and establish peace and reconciliation, and announce the result of their attempts to the court, which may be the success in conciliation or failure to achieve this goal. By examining these two Articles and clause 1 of Article 11 of this law, differences and common points in the arbitration and the Dispute Settlement Councils are as follows:
In the Dispute Settlement Council act, all of the family lawsuits can be referred to the council for peace and conciliation, but in arbitration law only divorce suit is referred to arbitration and in this regard Dispute Settlement Council has a greater advantage than arbitration law.

In the Dispute Settlement Council act, the court is not required to refer the case to the council (except in the cases of alimony, if the mount of relief is more than fifty million Rials), but if it deems expedient, It can do so. But in the arbitration law, by divorce suit, the court is required to refer the dispute to the arbitration. It seems that, if at least in the family suits, referring the case to Dispute Settlement Council were necessary, provided that the council was specialized and experts were in charge there, in this case a better result would be taken. In the Dispute Settlement Council, the hearing board is selected and introduced by the judge, but in the arbitration, the parties introduce the jury and the court accepts and selects them.

\subsection{Common points}

\subsection{Differences}

Both in the Dispute Settlement Council and in the jury, efforts should be 
made to establish peace and compromise between couples.

In both authorities, there is no obligation to the result, but anyway, the result of boards' effort must be reported to referring court of the dispute.

\section{Court performance in divorce suits}

The performance of the courts in the case of divorce can be divided in two categories based on the divorce requested:

\section{1 no-fault divorces}

Divorce granted at the woman's request (Khula) is known as no-fault divorce in the courts and judicial process, and many courts do not show any sensitivity about it. In fact, due to the large number of these petitions in some family courts, its hearing has a administrative process rather than a judicial process, and the courts consider the speed in hearing of these petitions, to the extent that the filing for issuance the certificate of incompatibility, hearing, the reference, getting the arbitrator's opinion, and the issuance of the incompatibility all are performed within one day; in such a way that during the petition, the couples introduce their arbitrators to the court. The court listens to the couples' declarations by convening the meeting, and states the reference in the process-verbal of the order.

The arbitrator that day also submits his opinion to the court, which may have already been previously prepared. Moreover, since everything is already clear, the court completes and signifies the judicial certificate of unmaintainable marriage, which is usually prepared and printed. At the same session, this certificate serves to the parties; they deny the right of contest from themselves and by award finality, parties remanded to marriage and divorce registry for performing divorce pronouncement and its registration.

These steps in the most favorable state and in case of court sensitivity may increase up to one to two months. However, this procedure only goes for the observance of the law. Additionally there is no sensitivity in arbitrator's acceptance or its determination by the court. As result who are chosen for arbitration that have lack of necessary information and expertise for doing their duties, or considered arbitration as a means of 
earning money and have lack of necessary incentives for creating peace and reconciliation between the parties.

\subsection{Divorce by the demand of one of the couples}

In this type of divorce, which is more from the wife, courts are paying more attention to family retention. By suit initiation in court of justice, before remanding the case to one of the family court branches, the case will be remanded to one of the Dispute Settlement Council to in this branch necessary action carried out to recognize the dispute subject, if possible, resolve it, and settle the reconciliation and consensus between couples.

The important point is that the success of the Dispute Settlement Councils to creating peace and reconciliation between the couples was unfortunately very low and this institution failed to meet expectations. It can be argued that, in addition to the lack of member's expertise in these affairs, the plurality of remanded cases to the councils has caused the members to getting into statisticism and dailiness.

The amendment of Dispute Settlement Council law and increase of its competences and change in their nature from a Quasi-judicial authority to the judicial authority has added to the council's problems in this regard. So that the only achievement of dispute parties (especially the women who are forced to initiate the suit), is delay and denial of justice in this unprofessional and newly established institute. However, if the council failed to resolve the problem, in spite of efforts will remand the case to the court of justice for judicial proceeding.

By determining the court branch, the process of judicial proceeding of the case begins and the court, according to the law if failed to reconciliation of two parties, required remanding the dispute to the arbitration. The manner of arbitrator's appointing and doing their duties is according to arbitration in no fault divorces. In addition, in the dispute time the arbitrator did not predict a solution regarding the continuation of marriage life or the impossibility of legislator. Moreover, the court will pay attention to the pending reasons by each of the couples in order to make a decision.

\subsection{An example of a court's decision}


In family courts, remanding a case to arbitrator is strictly for observance of formalities procedures and due to the couples disputes deepening before initiating divorce suit, the parties have no hope of improving the coupling relationship and divorce prevention, and the arbitrators are not serious about this matter too also court do not insist on continuing their marriage lives. To prove this claim, a sample of thousand judicial certificate of unmaintainable marriage that issued in family courts and all of them more or less similar to each other are mentioned.

In written judgment No. 8809978665200020 dated 2009-4-11, the first branch of the Delijan legal court stated:

$<$ Regarding the complaint submitted by... (Female) ...to.... (Male)... In response to the demand for the issuance of judicial certificate of unmaintainable marriage (no fault divorce) the court, according to the contents of the case and given documents, by considering marriage certificate No. .... and given that the court's advice was not effective in reconciliation of two parties, remanded the case to the arbitration that the selected arbitrators also after the

\section{6}

necessary consultations stated that, their efforts to create compromises and encourage the couples to continue their marriage life were unaffected and the couple insisting on divorce. Therefore, court by accepting the demand, according to law single particle and correction of rules regarding to divorce, judicial certificate of unmaintainable marriage were issued under the following conditions:

1- The couple has no marriage life and the wife have no child.

2- The wife donates all her financial rights including portion and alimony to the husband.

3- The type of divorce granted at a woman's request.

4- The parties are required to observance of the agreement dated 2009/4/4.

5- The issued certificate is certain and valid for three months. >>

What is remarkable in this decision is that, firstly the agreement between couples in divorce, which began with agreement draw up, dated 2009/4/4 and the time of issuing judicial certificate of unmaintainable marriage is exactly one week away. Secondly, the arbitral theory, which includes the recent 
agreement, has been draw up in the date of hearing and remanding the case to the arbitral and the court according to that attempted to issue the judicial certificate of unmaintainable marriage. Of course, with the status quo, except this is not feasible, because the time of remanding the case to arbitral lasted too late. The court, according to the law, considers the arrival of the arbitrator necessary at a time when the dispute culminated and left its destructive effects on the family and between couples. As a result, according to the writer's opinion, with the assumption of the court's rigor in this regard, and the reopening of many hearing sessions and lasting the legal procedure in order to resolve the aversion between couples, and the help of arbitrators regarding that disputes is rooted between couples, there is no result achieved. Therefore, in none of no fault divorces demand, the arbitrators have not required any success in reconciliation of two parties and if there is such that case, it is very rare and exceptional and cannot be counted.

\section{Arbitration in the Law of some} Muslim countries
In order to specify the place of arbitration rule in Iran's law in comparison with Muslim countries, in continuing the issues, the arbitral law of some Islamic countries will be referring:

\subsection{Egypt}

If the wife in life with husband claims the indigestion and embarrassment and cannot prove her claimed loss and the husband disapproves the wife's claim of losses, in this case, if the wife insists on her claim and divorce demanding, the court is required to determine two arbitrators.

The Egyptian legislator in the articles 11.7 of the personal status law stated the arbitrator's conditions and the manner of the arbitration. According to this article: $<<$ arbitrators should be fair and if possible, of couples relatives and if it is not possible, there are those who have the power to do correction between couples and know their way of living. The court must swear the arbitrator and set a deadline that should not exceed six months for them to draw up the arbitral theory. However, this deadline is extendable once for maximum time of three months. If during this time, the decision of arbitrators did not deliver to 
the court, it will consider as sign of their lack of unanimity regarding the couples (Esa Alpaghi, 113, 2005- Samani 290, 1999).

Arbitrators should put their efforts in order to know the aversion causes and strive for couple's reconciliation of two parties. In this regard, if they do not become successful in correction and reconciliation of couples, if misconduct recognized from the husband, arbitrators without taking anything from the wife's rights, will give opinion to irrevocable divorce. Nevertheless, if misconduct is from wife, by determining proper substitute, which wife can pay to the husband will suggest to divorce. In this case, if the misconduct is from husband, will give divorce suggestion without substitute or with substitute proper to wife's misconduct. Eventually, if the arbitrators failed to identify the culprit in the aversion, will give divorce suggestion without substitute to the court.

The arbitrators should submit their theory to the court, which is guarantee reasons and causes of their decisions and if they were not able to agree on unanimous decisions, the court will join a third party to them for solving the problem. If the arbitrators disputed with each other or do not submit their opinions within the determined deadline, the court will try to reconciliation the two parties. If this has not been successful and determined that there is no possibility of compromise and reconciliation between the couples and the wife insisting on divorce, by relinquishing of wife's whole or part of financial rights the award of irrevocable divorce will be issued (Rok Bana, 296,1996).

\subsection{Syria}

Article $112-115$ of Syria's personal status law is about this. "According to this article, if one of the couples claims that his or her life with his or her couple causes him or her loss that with his or her presence life is unbearable can demand divorce from the judge. If the claimant of loss was able to prove his claim, the court should try to make reconciliation and compromise between the parties, and if failed to reconciliation of two parties will issue the divorce award to irrevocable divorce.

But if the claimant fails to prove his claim, the judge will postpone the trial for a period that should not be less than one month and invites the parties to 
the compromise. If the claimant insists on his complaint and does not accept the compromise, the judge will select two arbitrators from the couple's relatives. If not possible, the arbitrators will be selected from among those who by the judge are recognized to have the power of reconciliation. The arbitrators swear that they will do their best to reconcile the couple (Istanbuli, 1997; Shafaghe, 1997).

The arbitrators are not required to find the cause of the couple's obstinacy. They make a meeting between the parties under the permission and the authority of the judiciary. No one other than those who were determined by the arbitrators has the right to attend the meeting. The absence of one of the couples does not prevent the holding of the verdict session. At that session, the arbitrators will endeavor to encourage the couple to compromise, and when they are disappointed, if the husband is obstinate, they will vote for irrevocable divorce. However, if the wife is obstinate or if the parties are equally obstinate, considering the level of obstinacy, the judge will vote for the divorce or the donation of all or a part of the dowry. If none of the parties is to blame, the judges can vote for the donation of the wife's financial rights, if she agrees. In the case of a dispute between the arbitrators, the judge will choose other arbitrators or a third party joins the arbitrators. In any case, the arbitrators are obliged to submit the report of their work and the results to the judge and the judge has the right to accept it and issue a verdict based on it or reject the report and replace the arbitrators by the other ones (Istanbuli, 1997).

\subsection{Iraq}

Article 41 of the Personal Status Law of Iraq on the loss to one of the couples during their common life has almost the same rules as Egyptian and Syrian laws.

In Iraq, each of the couples can go to court and ask for divorce, if they claim a loss during the life with the other. The same rule exists in a situation where couples fail to understand each other. This causes obstinacy. By initiating the described claim, the court must choose two arbitrators from the husband's side for the reconciliation of the two parties. So, the arbitrators must make efforts to correct and reconcile the relation between the couples. If they fail 
to do so, they must submit their viewpoints to the court, including:

1) The reasons and the causes of the dispute between the couples;

2) Introducing one of the couples as the cause of the dispute;

3) Introducing an opinion about the need for separation of the couples

After listening to the opinion of the arbitrators, the court will then decide to divorce them. If the couple refuses to divorce, the court will divorce the couple on behalf of the husband. Furthermore, in Iraqi law, only the claim of loss and obstinacy is not the reason for choosing the arbitrators, and the court does not have any reliability to make reconciliation between the couple. However, in the law of Egypt and Syria, this fact is considered. Moreover, when the wife is the cause of divorce, in Iraqi law, there is not any clear order about the dowry. Therefore, referring to Egyptian law, some of the professors believe in the void of the wife's dowry (Abdul Hamid, 1989,; Naji, 1970).

\section{Comparing the arbitration in Iran and other Islamic countries}

Comparing the arbitration in the law of Iran and other Islamic countries, the following points can be obtained:

In Iran's law, in all divorce claims, the case is referred to arbitration; whereas in other countries, if a wife claims indigestion and embarrassment during her common life with the husband but cannot prove her claimed loss, and the husband rejects the wife's claim, it is referred to arbitration to pay for the compensation. Therefore, in other cases it is not possible to refer the matter to the arbitrator.

In Iran's law, the arbitrators are not required to be just, but in Egyptian law, justice is one of the conditions of the arbitrators.

In Iran's law, the arbitrators are only obliged to make reconciliation between the couple, and if they fail to do so, they just report their failure to the court. However, in other Islamic countries, the arbitrators are required to determine the culpable of the obstinacy. Thus, on the basis of the fault of each of the couple, the court may determine the amount of the dowry that belongs to the wife and if the wife insists on divorce while the husband has no fault, the court can deduct the specified 
marriage portion or even deprive the wife of the dowry.

In Iran's law it is not specified that the court is bound to the opinion of the arbitrators' viewpoint, but in the law of the other countries, it is specified that the court is not liable to consider the arbitrators' view point.

Both in Iran's law and in the law of other countries, the arbitrators are mainly selected from the couple's relatives and it is a priority. The arbitrator must have the ability of reconciliating the two parties.

\section{Criticizing arbitration law}

The issue of arbitration and its scope in the pre-Islamic revolutionary laws was family disputes. After the Islamic Revolution, the legislator amended the law of arbitration and limited the scope of the arbitration. Under the current rules, the subject of arbitration is only divorce laws and the law does not require arbitration in other family claims. According to the investigations, one can claim that the current laws do not conform to the Qur'anic principles since the issue of arbitration is the particular concern of arbitration law in the Qur'an.
The legislator's policy in limiting the issue of arbitration, in addition to its incompatibility with the principles of the Qur'an, is also criticized for other reasons such as:

1) Limiting the scope of the arbitration is in conflicts with the interests and principles of the family. It seems that the legislator has underestimated the arbitration institution and its usage. Arbitration is a popular institution and, in fact, is a "family compromise court", which for various reasons is preferred to judicial review. To clarify this point, some benefits of arbitration are expressed. The most important benefits of arbitration are:

A) The family environment is the center of emotion. In this environment, it is impossible to take steps with the drastic scale of the law. So, as much as possible, the dispute should be settled emotionally. It is clear that in the judiciary emotions are not considered. 
B) In judicial courts, the parties to the dispute reveal any secrets they have to defend themselves. It is clear that the expression of family secrets to foreigners and abusers will exacerbate the feelings of a husband and wife. In such a situation, if the husband and wife are returned to their common life, the previous love, intimacy, and spiritual unity will not exist between them. The experiences have shown that the couples who have dispute and come to court, no longer have the same feeling of a husband and wife. It is obvious that at the family compromise session, family secrets are not revealed at the presence of the relatives due to the couple's shame. If the secret is revealed, because it is at the presence of the acquaintances and confidants, there will be no adverse effect.

C) Judges are often indifferent to the fate of the couples and their children. It is not very important for them that the two sides of the dispute reconcile and return to their homes and continue their common life, or they become separated while in the family comprise court, the story is quite the opposite. In this court, since the arbitrators are among the family members and have shared interests with couples, they are not indifferent to their future. Therefore, they endeavor to fix the relation between the husbands and wives (Makarem Shirazi, 1994).

Considering what has been said, it turns out that the arbitration domain develops in such a way that it includes other family litigation. Arbitration is in the best interests of the family since article 10 of Iran's Constitution states that laws and regulations must be established and amended in order to strengthen family relations. Thus, it says: "Since the family is the fundamental unit of the Islamic society, all relevant laws, regulations and plans must be made to facilitate the formation of the family, the safeguarding of its sanctity and the stability of family relations based on Islamic law and ethics. "

Thus, the revision of arbitration laws has led to the "stability in family relations". So the development of arbitration domain is the legislator's major request.

2) Restricting the domain of the arbitration to divorce claims is contrary to the objectives and 
policies of the judiciary. The reasons for this are as follows:

A) The judiciary is faced the shortage of judicial and human resources. In such a situation, the lawmaking policy of the country should not be in the direction of increasing the recourse to the judiciary. If the domain of the arbitration develops in a way that it includes other family claims, this will reduce the recourse to the court of justice. On the contrary, limiting the domain of arbitration to divorce claims increases the recourse to the court of justice. On the contrary, to limit judgment scope to divorce claims cause people to refer to the administration of justice increasingly.

B) Judicial investigations are prolonged due to judgment complexities and also high volume pending files. Prolonged investigation in judicial courts cause people to be wandering and in addition to, it is not advisable for the family. Prolonging family litigation leads to a worsening of marital relationships.
Conversely, the investigation of couples' differences in the family peace court of law is without formalities and will be promptly implemented.

C) Judicial proceedings are costly. For example, a woman should pay legal fees at the time of presenting complaint while she refers to the court for receiving alimony, marriage portion and so on. However the statistical study show when Iranian women refer to family courts to receive financial rights have been unsuccessful in many cases, despite spending a lot of time and cost. (Hedayatnia, 2004). But at the family peace court, there is no legal fees to a husband or a wife.

Now, the question arises, with regard to the above, is the limitation of the scope of arbitration to the interest of the judicial system and the family?

3) The time to refer to arbitration is not suitable. Judgment in the Quran is a preventive measure and is formed by signs of disagreement; hence, there is a greater hope for the outcome, 
while the arbitration is not the case in the current law; the court will hold arbitration sessions when disputes of the parties have rooted and the parties decide to divorce (ibid).

4) The court is not compelled to make divorce representation, initially to refer the matter to arbitration, but the court must make peace between couples and if it fails to resolve the claim, it will refer the matter to judgment. This method has several drawbacks:

A) According to the verse of the Holy Qur'an, an organization tribunal is for family peace, not a judicial organization. The environment and space in the court, even if they intend to have peace and compromise are a judicial environment, and the parties seek to defend their functions in order to satisfy the judges, and in this way they usually do everything. This morale and function in some materials not only does not help to improve relations, but also leads to greater hostility and acceleration in separation (Makarem Shirazi, 1998).

B) Considering the fact that the outcome of the claim is not effective in the work of the court, and the courts are more concerned with resolving hostility, have never sensitivity of the judges who depend on the parties, and their separation or peace directly or indirectly affect on their lives (ibid).

C) In case the court actually intends to make peace and compromise the couples, It is not possible to do this for court judge due to the large number of cases and numerous files present in the court and patience, tolerance and abundant time which are needed for considering the family claims.

5) In the law, two arbitrators have been indicated, one from the party of woman and the other from the party of man. Considering this fact that the possibility of disagreement between the judges, for example, the arbitrator of husband vote to the possibility of continuation of 
the life and arbitrator of the wife vote to separation and noncompromise and settlement, it is not specified that court must accept which opinion.

This objection is more patent concerning note 2 , single article of the law on amending the provisions on divorce, as according to this note, the written report of the impossibility of compromise in accordance with all the terms and conditions contained in the marriage documents of the Islamic Republic of Iran and the determination of the assignment and the competency of the children's guardianship and settlement of financial matters with the signing of the arbitrators of the husband and the divorced wife as well as the written certificate of mental health of the couples will be delivered to the court in case they are suspected of a particular civil court.

6) The rate of credibility of the arbitrators view and the assumption or lack of assumption of the court to this theory is not specified in the law; in other words, it is not determinate if the court is obligated to accept the arbitrators theory based upon possibility of continuation of life?

\section{9) Suggestions}

A) Many couples' disputes arise from the lack of sufficient knowledge of their rights and duties against each other. Therefore, in order to pursue a judicial hygiene policy, shortterm training courses are required to be held for married couples at the beginning of marriage. Considering this fact that it is now mandatory to participate in family planning classes at the beginning of marriage, the behavior training courses in the family in terms of psychology, social, cultural and legal in coordination with the judicature and the welfare organization at the beginning of the marriage can be hold, and the couples are forced to participate in order that the young girls and boys attempt to build the families with more knowledge and information and become familiar with their duties in the family and 
the effects of failure to do the work in front of others.

That what the Holy Quran's has stated in the judgment arbitration shall be acted upon; namely any dispute and family argument propounded in the court shall be referred to arbitration in order that the source of the dispute through court of peace is extirpated and the disagreement between the couples shall not be extended. In fact, by amending the law, when couples should have the right to refer to the ruler and the dispute settlement council at the beginning with the presence of arbitrators in specialized agencies such as welfare, and counselors, psychologists and family counselors and intervention centers in family affairs who certify that the efforts of the judges and experts have not been effective in compromising.

B) In addition to family complexes, the number of arbitration chambers comprised of legal experts, family counselors and psychologists have to be established, and the court, by joining two persons selected by the spouses to each chamber who hear the dispute of the couples, take the necessary action to prevent the severity of dispute and divorce.

C) In Iranian laws, the role of arbitrators is summarized only in making peace and compromise, which in case of failure, informs the court and does not have any other duties. While in some Islamic countries, in the case of failure in making peace and compromise between couples, the arbitrators are obligated to declare the faulty in making aversion on the court and rate of his/her fault to the court. Therefore, Iranian lawmakers, like the rights of these countries, are required to raise the role of arbitrators in determining the faulty for making aversion and dispute.

D) The court assumption to arbitrators view is appropriate to be amended in Iranian arbitration law. This will help the court really achieve the truth, and in addition, can compel a husband or a wife who disobeys, to perform the duty in front of the other so that the matter of dispute is extirpated. 
Therefore, it is recommended to add the following articles to the law of family protection propounded in the parliament:

- The judiciary is bound to establish necessary number of arbitration chambers composed of legal experts, family counselors as well as family courts to help the court to resolve family disputes.

- Courts are obliged to refer any family dispute (including husband's compulsion to pay, wife's compulsion to obedience, divorce and etc.) first to arbitration chamber. In case the arbitration chamber failed to make peace and compromise, the file will be reimbursed to the court chamber for judicial proceeding.

Note: The value of the arbitration chamber view is like the value of expert view in other claims. "

\section{References:}

Ibn Qadam (1972). Moghni and Sharhe Alkabir. Beiroot, Dalrolketab Alarabi.

Istanbooli, Adib (1997M), AlSighe Alghanooniyah, Ledawi Alahwal Alshakhsiah, Damascus, Nashro Almektabeh Alghanooniyah Ch 2.
Bana, Kamal Saleh (1996m), Alsigha Alghanooniyyah Ledawi, Alahwal Alshakhsiah, Cairo, Nashr Almaktab AlJame Alhadis Ch 3.

Jabei Alameli (Shahid Avval), Zein Aldin (1416 Gh), Masalek Alafham Fu Alhelal and Alharam, Qom: Nashre Maaref Islami Ch 1.

Helli (Mohaghegh), Yahya ben Sa'id (1405 Gh), Sharayei Aleslam Fi Alhelal and Alharam, Qom, Entesharate Amir.

Heydar, Ali (Bita), Dorare Alhokam Sharhe Majalleye Alahkam. BeirutBaghdad: Maktabeye Alnehzah.

Samani, Hasan Ali (1990m), Alvajiz Fi Ahwale Alshakhsiah, Cairo, Daro Alkotobe Alghanounieh, Ch1.

Sivasi and Ghazizadeh (1316 Gh). Fatho Alghadir, Matbaeye Alkobra Alamiriyeh.

Shafeghah, Mohammad Fahr (1997m), Sharhe Ahkam Alhawal Alshkhsiyah, Damascus, Moasseseye Alnoori Ch1.

Shirazi, Seyyed Mohammad Hosseini, (1419), Alfegh, Alghanoon, Beirut- 


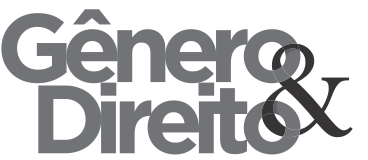

Periódico do Núcleo de Estudos e Pesquisas sobre Gênero e Direito

Centro de Ciências Jurídicas - Universidade Federal da Paraíba

V. 8 - No 01 - Ano 2019

ISSN | 2179-7137 | http://periodicos.ufpb.br/ojs2/index.php/ged/index
Lebanon, Markaze Alrasool Alazam (S)

Leltahghighe Va Alnashre, Q2.

Taheri, Habibollah, (1418), Hoghooghe

Madani, Qom: Daftare Entesharate

Eslami Vabasteh Be Modarresin Hozeh

Elmiye Ghom Ch 3, J 2.

Ameli, Shahid Sani, Zeino Aldin Ibne Ali, (1413), Masalek Alafham Ela

Tanghih Sharae Aleslam, Ghom, Moasseseye Almaref Aleslamiyeh Ch 1, $\mathrm{J} 1$.

Ameli, Horr, Mohammed Ibn Hasan, (1409)Vassele Alshieye Qom, Mosseseye Ale Albeit Alayhe Alsalam, Ch 1.

Abdul Hamid, Nezam Aldin (1989m), Ahkame Anhelal Aghde Alzevaj Fi Feghe Aleslami Va Alghnoon Alaraghi, Baghdad, Nashre Beit Alhakame Ch1.

Isa Alfeghi, Amroo (2005m), Almosooeh Alshameleh Fi Ahwal Alshakhsiyyah, Cairo, Darol Kotobe Alghanooniyeh Ch1.

Katouzian, Nasser (1995), Hoghooghe Madani (Khanevadeh) Tehran, Sherkate Enteshar Ba Hamkari Bahmane Borna.
Makarem Shirazi, Naser Va Hamkaran (1996), Tafsire Nemooneh, Tehran, Dar Alkotobe Eslamiyah, Ch 3.

Naji, Mohsen (1970m), Sharhe Ghanoon Alahval Alshakhsiyyah, Baghdad, Nashre Alrabeteh Ch1.

Najafi, Saheb Aljavaher (1976), Mohammad Hassan, Javaher Alkalam Fi Sharhe Sharae Aleslam, Beiroot Labanon, Dare Ehyae Alteras Alarabi, Ch $7, \mathrm{~J} 40$.

Hedayat Niya, Farajollah (2007), Falsafeye Hoghoogh Khanevadeh, Tehran, Ravabete Omoomi Shoraye Farhangi, Ejtemaei Zanan Ch 1 